\title{
Increase of endocan, a new marker for inflammation and endothelial dysfunction, in acute kidney injury
}

\author{
(D) Murat Gunay, (D) Cuma Mertoglu \\ Department of Clinical Biochemistry, Erzincan University Faculty of Medicine, Erzincan, Turkey
}

\begin{abstract}
OBJECTIVE: In this study, the clinical relevance of the levels of serum endocan and 25-hydroxyvitamin $D$ [25(OH)D] was investigated in patients with acute kidney injury (AKI). Endocan or the endothelial cell-specific molecule 1 is a soluble proteoglycan secreted by vascular endothelial cells. It plays a significant role in immunity, inflammation, and endothelial function.

METHODS: A total of 39 patients with AKI (19 females, 20 males) and 38 healthy individuals (18 females, 20 males) were included in the study. The levels of serum endocan, vitamin $D$, and other biochemical parameters were compared between the two groups.

RESULTS: In the AKI group, the values of serum creatinine, endocan, parathormone, phosphorus, and uric acid were found to be higher, and the total protein, albumin, and calcium levels were lower compared to the control group. There was no difference between the two groups in terms of the serum vitamin $D$, magnesium, alkaline phosphatase, and gamma-glutamyl transferase.
\end{abstract}

CONCLUSION: In patients with AKI, an increased endocan level is a significant marker of inflammation and endothelial injury. In addition, these patients experience vitamin D deficiency.

Keywords: Acute kidney injury; endocan or endothelial cell-specific molecule 1 (ESM 1); vitamin D.

Cite this article as: Gunay M, Mertoglu C. Increase of endocan, a new marker for inflammation and endothelial dysfunction, in acute kidney injury. North Clin Istanb 2019;6(2):124-128.

A cute kidney injury (AKI) is defined as the rapid loss of renal function, which leads to the accumulation of the products of nitrogen metabolism (urea and creatinine) or a reduced urine output [1]. AKI is a syndrome frequently seen in hospitalized patients, and it has distressing outcomes. The current diagnostic AKI method is measuring the level of serum creatinine; however, due to the insensitivity of this marker to the changes in the renal function, there is a need to investigate the efficiency of alternative biomarkers with a higher sensitivity and specificity to achieve an early and accurate diagnosis [2].

The endocan-specific (also known as the endothelial cell-specific) molecule 1 (ESM-1) is a soluble proteogly- can secreted by the cells of the vascular endothelium [3]. It plays a significant role in inflammation, rearrangement of endothelial cytoskeleton, functioning of lymphocytes, and upregulation of several adhesion molecules [4]. Recent studies have shown that endocan can be used as a biomarker for the assessment of inflammatory, cardiovascular, and chronic kidney diseases as well as cancer [3, 5-7]. It is also known that inflammation and endothelial injury play a significant role in AKI pathogenesis. The impairment of the endothelial and smooth muscle cells plays critical roles in the pathophysiology of AKI. When the endothelium is injured, the endocan tissue level increases [8]. 
Vitamin D deficiency is commonly seen in all ages groups throughout the world [9] and presents as a risk factor for not only the development of infectious, autoimmune, and cardiovascular diseases, but also osteoporosis, diabetes, and cancer [10]. In chronic kidney disease, 25-hydroxyvitamin $\mathrm{D}[25(\mathrm{OH}) \mathrm{D}]$ deficiency is very common and associated with the causes of mortality and morbidity [11]. In addition, in recent years, AKI has been associated with a high risk for the progression of chronic kidney disease and end-stage renal disease [12]. It has also been reported that inflammation plays a role in both vitamin D deficiency [13] and AKI etiopathogenesis $[14,15]$. However, to date, only a limited number of studies have investigated the level of vitamin D in AKI.

Given the above-mentioned relationships of 25-hydroxyvitamin $\mathrm{D}$ and endocan with inflammation and endothelial function, we considered these two factors to be two potential parameters that could be used as new markers for diagnosing AKI and elucidating its etiopathogenesis.

\section{MATERIALS AND METHODS}

Thirty-nine patients (19 females, 20 males) diagnosed with $\mathrm{AKI}$ at the polyclinics, emergency service and intensive care unit, of our hospital between December 2015 and June 2016 and 38 ( 18 females, 20 males) healthy volunteers were included in this prospective study. All the participants were older than 18 years. The exclusion criteria were acute diseases such as myocardial infarction, sepsis, acute respiratory distress syndrome, or chronic diseases such as diabetes mellitus, rheumatic, and cardiovascular diseases or using any kind of medications. The study protocol was performed according to the principles of the Declaration of Helsinki. All subjects gave their written informed consent for participation in the study, which was approved by the clinical research local ethics committee of Erzincan University.

The AKI diagnosis was made based on the presence of one of the following: an increase in serum creatinine by $\geq 0.3 \mathrm{mg} / \mathrm{dl}$ within 48 hours; an increase $\geq 1.5$-fold from a known or assumed baseline, or a reduction in urinary output by less than $0.5 \mathrm{ml} / \mathrm{kg} / \mathrm{h}$ over 6 hours [1].

The blood samples taken from the participants, only for patient admission at the time of enrollment in patients with $\mathrm{AKI}$, were immediately centrifuged and stored at $-80{ }^{\circ} \mathrm{C}$ until use. The endocan level of each sample was measured using the enzyme-linked immunosorbent as- say method [Sun Red Human (ECSM1) ELISA kit]. The results were recorded in $\mathrm{ng} / \mathrm{L}$. The intra-assay and inter-assay coefficients of variation of the endocan were found to be $10 \%$ and $12 \%$, respectively, and the minimum detectable concentration was $7.506 \mathrm{ng} / \mathrm{L}$.

The biochemical tests were analyzed on a Beckman Coulter Olympus AU2700 analyzer, and the 25-hydroxyvitamin $\mathrm{D}$ and parathormone $(\mathrm{PTH})$ were measured using the Siemens Centaur XP immunoassay system. The corrected calcium was calculated with the following equation: corrected calcium $=$ serum calcium + $\left[0.8^{*}(4\right.$-serum albumin concentration $\left.)\right][16]$.

\section{Statistical Analysis}

The Statistical Package for Social Sciences Software for Windows version 18.0 (SPSS Inc., Chicago, IL, USA) was used for the statistical analysis of the demographic and clinical data of the sample. The normality assumption was checked using the Kolmogorov-Smirnov test. Differences between the two groups were evaluated by the independent $t$-test when the assumptions of this parametric test were met. The $\mathrm{p}$-value of $<0.05$ was considered as statistically significant.

\section{RESULTS}

No significant difference was found between the study and control groups in terms of gender $(p=0.912)$, weight $(71 \pm 10.6 \mathrm{~kg}, 72.4 \pm 11.3 \mathrm{~kg}, \mathrm{p}=0.589)$, height $(167.9 \pm 9$ $\mathrm{cm}, 165.3 \pm 5 \mathrm{~cm} \mathrm{p}=0.172$ ), and body mass index (BMI, $25.5 \pm 2.3 \mathrm{~kg} / \mathrm{m}^{2}, 27.6 \pm 4.5 \mathrm{~kg} / \mathrm{m}^{2} \mathrm{p}=0.112$ ); however, the mean age was significantly higher in the study group compared to the healthy individuals (72 years and 38.5 years, respectively; $\mathrm{p}<0.001)$. There is no any relationship between BMI, age, and levels of 25-hydroxyvitamin $D$, endocan ( $p>0.05)$.

In the study group, serum creatinine, blood urine nitrogen, endocan, parathyroid hormone, phosphorus, and uric acid values were found to be higher, while total protein, calcium, albumin, and calcium corrected for albumin were found to be lower compared to the control group. However, there were no significant differences between the two groups in terms of the serum vitamin D, magnesium, alkaline phosphatase (ALP), and gamma-glutamyl transferase (GGT) values (Table 1). According to a receiver operating characteristic (ROC) analysis based on the cut-off value of $>220$, endocan has a sensitivity of $59 \%$, specificity of $76.3 \%$, and area under curve 
TABLE 1. Comparison of biochemical data between AKI and control groups

\begin{tabular}{lccc} 
Parameters & $\begin{array}{c}\text { Controls } \\
(\text { Mean } \pm \text { SD })\end{array}$ & $\begin{array}{c}\text { AKI } \\
(\text { Mean } \pm S D)\end{array}$ & $p$ \\
\hline BUN mg/dL & $24.8 \pm 7.6$ & $129.3 \pm 85.1$ & $<0.001^{\text {a }}$ \\
Creatinine $\mathrm{mg} / \mathrm{dL}$ & $0.9 \pm 0.1$ & $3.0 \pm 1.5$ & $<0.001^{\text {a }}$ \\
Total protein g/dL & $7.14 \pm 0.56$ & $6.67 \pm 0.73$ & $0.003^{\mathrm{b}}$ \\
Albumin g/dL & $4.23 \pm 0.33$ & $3.57 \pm 0.62$ & $<0.001^{\text {a }}$ \\
25-hydroxyvitamin D & & & \\
ng/ml & $11.3 \pm 12.9$ & $11.1 \pm 9.3$ & 0.925 \\
PTH pg/ml & $56.9 \pm 30.6$ & $111.1 \pm 63.7$ & $<0.001^{\text {a }}$ \\
Calcium mg/dL & $9.3 \pm 0.4$ & $8.7 \pm 0.8$ & $0.001^{\text {c }}$ \\
Corrected calcium & $9.3 \pm 0.4$ & $8.8 \pm 1.3$ & $0.025^{\mathrm{b}}$ \\
Magnesium mg/dL & $2.1 \pm 0.1$ & $2.2 \pm 0.6$ & 0.212 \\
Phosphorus mg/dL & $3.6 \pm 0.6$ & $4.8 \pm 1.7$ & $0.001^{\mathrm{c}}$ \\
GGT U/L & $19.6 \pm 7$ & $22.3 \pm 11$ & 0.262 \\
ALP U/L & $97.6 \pm 24$ & $92.5 \pm 17$ & 0.303 \\
Uric acid mg/dL & $5.2 \pm 1.5$ & $9.3 \pm 3.9$ & $<0.001^{\text {a }}$ \\
Endocan ng/L & $199 \pm 56$ & $336 \pm 289$ & $0.006^{\mathrm{b}}$ \\
\hline
\end{tabular}

a: $p<0.001$; b: $p<0.05$; $: p=0.0001$; AKI: Acute kidney injury; ALP: Alkaline phosphatase; BUN: Blood urine nitrogen; GGT: Gamma glutamyl tansferase; PTH: Parathyroid hormone; SD: Standard deviation.

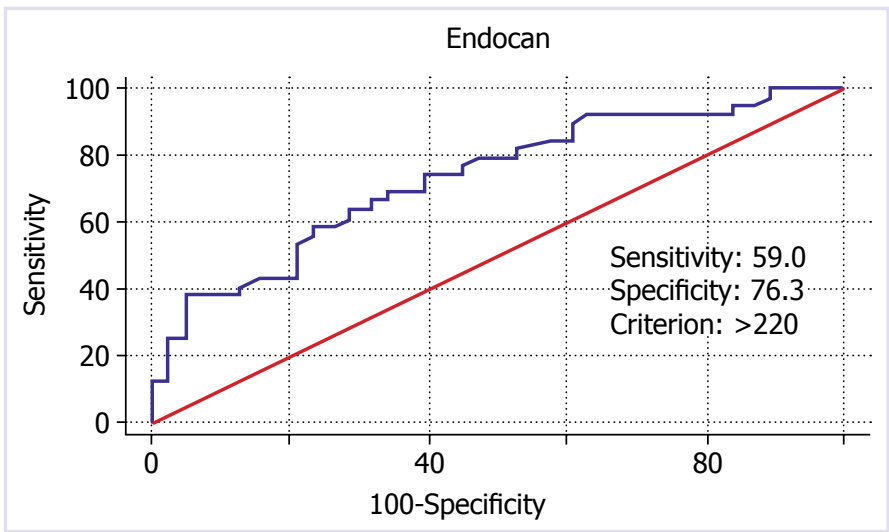

FIGURE 1. Receiver operating characteristic analysis of serum endocan for the diagnosis of acute kidney injury.

of 0.733 (95\% confidence interval: $0.620-0.827$ ) for the diagnosis of AKI (Fig. 1).

\section{DISCUSSION}

The results of this study revealed a higher endocan level in patients diagnosed with AKI when compared to healthy individuals. However, vitamin D deficiency was observed in both groups. This clearly demonstrates the role of inflammation and endothelial dysfunction in AKI etiopathogenesis. Furthermore, the ROC analysis confirmed a high sensitivity and specificity of endocan $(59 \%$ and $76.3 \%$, respectively) in the diagnosis of AKI. However, since these values were obtained against a healthy control group and considering the increased endocan levels in the presence of several other diseases, we suggest that the specificity of endocan might be lower, and therefore the physicians should take precautions when performing a differential diagnosis of AKI.

It is not yet clear whether the increased endocan level in patients with kidney diseases is due to elevated secretion or a reduced clearance of ESM-1. The clearance mechanism of endocan has also not been clarified. Therefore, in this study, the increased level of endocan found in cases with a reduced kidney function may be associated with either increased production or reduced clearance of this protein [6].

Su et al. reported a correlation between serum endocan levels and chronic kidney disease, and they associated the increased endocan levels with the progression of graft renal dysfunction. In the same study, the researchers found a correlation between tumor necrosis factor alpha (TNF- $\alpha$ ), an inflammatory cytokine known to stimulate the endothelial cell activation and damage, and serum endocan [17]. In a similar study conducted with patients that had undergone renal transplantation, endocan was reported to be a sensitive and specific marker of acute rejection, indicating the degree of cell damage in renal allografts [18].

Yilmaz et al. investigated the plasma endocan level of patients with chronic kidney disease and found it to be correlated negatively with the estimated glomerular filtration rate (eGFR) and positively with pentraxin 3 and high-sensitivity C-reactive protein (hsCRP), markers of inflammation. Furthermore, the authors used two vascular abnormalities of flow-mediated vasodilatation and carotid intima-media thickness to assess endothelial dysfunction and demonstrate their association with endocan. In addition, one of the most important findings was presented as the association between the elevated plasma endocan level and the increased risk of cardiovascular diseases and all-cause mortality [7].

Serum endocan level has been reported to be higher in hypertensive patients and attributed to its association with carotid intima-media thickness and hsCRP. This relationship has been attributed to endothelial dysfunction and inflammation [19]. 
A high plasma endocan level has been suggested as a prognostic marker of immunoglobulin A nephropathy through demonstrating advanced pathologic grades and a rapid decline in eGFR [20]. Chen et al. found the inflammatory response of ischemic AKI to be associated with an increased expression of the adhesion molecules of the endothelium [21]. All these results are consistent with those reported in the present study.

In this study, the vitamin D levels of the study and control groups were similar, both indicating a deficiency. A $25(\mathrm{OH}) \mathrm{D}$ level of $20 \mathrm{ng} / \mathrm{mL}$ indicates vitamin D deficiency, $21-29 \mathrm{ng} / \mathrm{mL}$ refers to insufficiency, a value $>30 \mathrm{ng} / \mathrm{mL}$ represents a sufficient level (preferred range, $40-60 \mathrm{ng} / \mathrm{mL}$ ), and a value $>150 \mathrm{ng} / \mathrm{mL}$ is considered to be vitamin D intoxication [9].

In cases of end-stage renal disease, the serum vitamin D levels have an inverse relation with endotheliumdependent dilation, vascular endothelial function, and vascular endothelial inflammation [22]. In their study, Braun et al. concluded that the $25(\mathrm{OH}) \mathrm{D}$ deficiency was a significant predictor of AKI and mortality in critically ill patient population [23]. Goncalves et al. created an AKI rat model induced by ischemia/reperfusion damage, and demonstrated that vitamin $\mathrm{D}$ deficiency increased tubulointerstitial damage and the formation of interstitial fibrosis and thus aggravated the progression of chronic kidney disease [24]. Similarly, in another experimental study on rats, the group, in which both vitamin D deficiency and ischemia/reperfusion AKI were induced, was found to experience a higher decline in renal function, having a higher excretion of urinary protein, greater renal tubular damage and lymphocyte infiltration compared to the group that was only subjected to ischemia/reperfusion AKI. Based on this result, the authors concluded that vitamin D deficiency aggravated AKI [25]. In another study, the vitamin D deficiency in AKI patients was inversely related to the severity of sepsis and mortality [26].

The results of previous research as well as the present study show that vitamin D deficiency is commonly seen in patients with AKI. In this study, the absence of a significant difference between the study and control groups in terms of the vitamin D levels can be attributed to the generally low levels of vitamin D observed throughout the world for all age groups and both genders [9].

In this study, the PTH and P levels were found to be higher and $\mathrm{Ca}$ and albumin lower in the study group than the control group. This is also consistent with ear- lier reports $[27,28]$. Serum uric acid was higher in the study group, which has previously been attributed to hyperuricemia and the crystalline and non-crystalline effects of uric acid increasing the risk for AKI [29].

The presents study showed no significant difference between the two groups concerning serum ALP and GGT levels. Similarly, other researchers have demonstrated that despite the increased levels of brush border enzymes in urine indicating cell necrosis, serum levels do not reflect the same change $[30,31]$.

In conclusion, this study is significant in terms of being the first report, to the best of our knowledge, in the literature on the endocan levels of patients with AKI. Serum endocan levels were found to increase in the presence of AKI secondary to inflammation and endothelial damage. Another significant finding is the common vitamin $\mathrm{D}$ deficiency among these patients.

Conflict of Interest: The authors stated that there are no conflicts of interest regarding the publication of this article.

Financial Disclosure: This study was supported by the Erzincan University scientific research projects office. The funding organization played no role in the study design; the collection, analysis, and interpretation of data; the writing of the report; or the decision to submit the report for publication.

Authorship Contributions: Concept - MG; Design - MG; Supervision - MG; Materials - MG, CM; Data collection and/or processing - MG, CM; Analysis and interpretation - MG; Writing - MG; Critical review - MG, CM.

\section{REFERENCES}

1. Kellum JA, Lameire N, Aspelin P, Barsoum RS, Burdmann E A, Goldstein SL, et al. KDIGO Clinical Practice Guideline for Acute Kidney Injury. Available at: https://kdigo.org/wp-content/uploads/2016/10/ KDIGO-2012-AKI-Guideline-English.pdf. Accessed Jun 30, 2019.

2. Waikar SS, Bonventre JV. Biomarkers for the diagnosis of acute kidney injury. Nephron Clin Pract 2008;109:c192-7. [CrossRef]

3. Sarrazin S, Adam E, Lyon M, Depontieu F, Motte V, Landolfi C, et al. Endocan or endothelial cell specific molecule-1 (ESM-1): a potential novel endothelial cell marker and a new target for cancer therapy. Biochim Biophys Acta 2006;1765:25-37. [CrossRef]

4. Afsar B, Takir M, Kostek O, Covic A, Kanbay M. Endocan: a new molecule playing a role in the development of hypertension and chronic kidney disease? J Clin Hypertens (Greenwich) 2014;16:914-6. [CrossRef]

5. Balta S, Mikhailidis DP, Demirkol S, Ozturk C, Celik T, Iyisoy A. Endocan: A novel inflammatory indicator in cardiovascular disease? Atherosclerosis 2015;243:339-43. [CrossRef]

6. Lee HG, Choi HY, Bae JS. Endocan as a potential diagnostic or prognostic biomarker for chronic kidney disease. Kidney Int 2014;86:1079-81.

7. Yilmaz MI, Siriopol D, Saglam M, Kurt YG, Unal HU, Eyileten T, et al. Plasma endocan levels associate with inflammation, vascular abnormalities, cardiovascular events, and survival in chronic kidney disease. Kidney Int 2014;86:1213-20. [CrossRef] 
8. Bonventre JV, Yang L. Cellular pathophysiology of ischemic acute kidney injury. J Clin Invest 2011;121:4210-21. [CrossRef]

9. Holick MF, Binkley NC, Bischoff-Ferrari HA, Gordon CM, Hanley DA, Heaney RP, et al. Evaluation, treatment, and prevention of vitamin D deficiency: an Endocrine Society clinical practice guideline. J Clin Endocrinol Metab 2011;96:1911-30. [CrossRef]

10. Dusso AS, Brown AJ, Slatopolsky E. Vitamin D. Am J Physiol Renal Physiol 2005;289:F8-28. [CrossRef]

11. Liu WC, Wu CC, Hung YM, Liao MT, Shyu JF, Lin YF, et al. Pleiotropic effects of vitamin D in chronic kidney disease. Clin Chim Acta 2016;453:1-12. [CrossRef]

12. D'hoore E, Neirynck N, Schepers E, Vanholder R, Verbeke F, Van Thielen M, et al. Chronic kidney disease progression is mainly associated with non-recovery of acute kidney injury. J Nephrol 2015;28:70916. [CrossRef]

13. Kankova M, Luini W, Pedrazzoni M, Riganti F, Sironi M, Bottazzi B, et al. Impairment of cytokine production in mice fed a vitamin D3-deficient diet. Immunology 1991;73:466-71. [CrossRef]

14. Day YJ, Huang L, Ye H, Li L, Linden J, Okusa MD. Renal ischemia-reperfusion injury and adenosine $2 \mathrm{~A}$ receptor-mediated tissue protection: the role of CD4+ T cells and IFN-gamma. J Immunol 2006;176:3108-14. [CrossRef]

15. Siew ED, Ware LB, Ikizler TA. Biological markers of acute kidney injury. J Am Soc Nephrol 2011;22:810-20. [CrossRef]

16. Dickerson RN, Alexander KH, Minard G, Croce MA, Brown RO. Accuracy of methods to estimate ionized and "corrected" serum calcium concentrations in critically ill multiple trauma patients receiving specialized nutrition support. JPEN J Parenter Enteral Nutr 2004;28:133-41.

17. Su YH, Shu KH, Hu CP, Cheng CH, Wu MJ, Yu TM, et al. Serum Endocan correlated with stage of chronic kidney disease and deterioration in renal transplant recipients. Transplant Proc 2014;46:323-7. [CrossRef]

18. Li S, Wang L, Wang C, Wang Q, Yang H, Liang P, et al. Detection on dynamic changes of endothelial cell specific molecule- 1 in acute rejection after renal transplantation. Urology 2012;80:738.e1-8. [CrossRef]

19. Balta S, Mikhailidis DP, Demirkol S, Ozturk C, Kurtoglu E, Demir $\mathrm{M}$, et al. Endocan-a novel inflammatory indicator in newly diagnosed patients with hypertension: a pilot study. Angiology 2014;65:773-7.
20. Lee YH, Kim JS, Kim SY, Kim YG, Moon JY, Jeong KH, et al. Plasma endocan level and prognosis of immunoglobulin A nephropathy. Kidney Res Clin Pract 2016;35:152-9. [CrossRef]

21. Chen J, John R, Richardson JA, Shelton JM, Zhou XJ, Wang Y, et al. Toll-like receptor 4 regulates early endothelial activation during ischemic acute kidney injury. Kidney Int 2011;79:288-99. [CrossRef]

22. London GM, Guérin AP, Verbeke FH, Pannier B, Boutouyrie P, Marchais SJ, et al. Mineral metabolism and arterial functions in end-stage renal disease: potential role of 25-hydroxyvitamin D deficiency. J Am Soc Nephrol 2007;18:613-20. [CrossRef]

23. Braun AB, Litonjua AA, Moromizato T, Gibbons FK, Giovannucci E, Christopher KB. Association of low serum 25-hydroxyvitamin $\mathrm{D}$ levels and acute kidney injury in the critically ill. Crit Care Med 2012;40:3170-9. [CrossRef]

24. Gonçalves JG, de Bragança AC, Canale D, Shimizu MH, Sanches TR, Moysés RM, et al. Vitamin D deficiency aggravates chronic kidney disease progression after ischemic acute kidney injury. PLoS One 2014;9:e107228. [CrossRef]

25. de Bragança AC, Volpini RA, Canale D, Gonçalves JG, Shimizu MH, Sanches TR, et al. Vitamin D deficiency aggravates ischemic acute kidney injury in rats. Physiol Rep 2015;3. pii: e12331. [CrossRef]

26. Leaf DE, Waikar SS, Wolf M, Cremers S, Bhan I, Stern L. Dysregulated mineral metabolism in patients with acute kidney injury and risk of adverse outcomes. Clin Endocrinol (Oxf) 2013;79:491-8. [CrossRef]

27. Druml W, Schwarzenhofer M, Apsner R, Hörl WH. Fat-soluble vitamins in patients with acute renal failure. Miner Electrolyte Metab 1998;24:220-6. [CrossRef]

28. Wolf M, Thadhani R. Vitamin D in patients with renal failure: a summary of observational mortality studies and steps moving forward. J Steroid Biochem Mol Biol 2007;103:487-90. [CrossRef]

29. Hahn K, Kanbay M, Lanaspa MA, Johnson RJ, Ejaz AA. Serum uric acid and acute kidney injury: A mini review. J Adv Res 2017;8:529-36.

30. Kokkoris S, Pipili C, Grapsa E, Kyprianou T, Nanas S. Novel biomarkers of acute kidney injury in the general adult ICU: a review. Ren Fail 2013;35:579-91. [CrossRef]

31. Ferguson MA, Vaidya VS, Bonventre JV. Biomarkers of nephrotoxic acute kidney injury. Toxicology 2008;245:182-93. [CrossRef] 